\title{
Church Accounting Concepts with the Understanding of God's Kingdom
}

\author{
Anita Nisa Kambey \\ Manado State University, Jl. Raya Tondano, Koya, Tondano Sel., Kabupaten Minahasa, Sulawesi Utara 95618, Indonesia \\ anitakambey@gmail.com
}

ARTICLE INFO

Article history

Received 7 January 2021

Revised 18 March 2021

Accepted 28 April 2021

Keywords:

Biblical accounting;

Church accounting;

Kingdom of God.

\section{ABSTRACT}

The purpose of this article is to present the concept of church accounting with an understanding of the Kingdom of God. The construction employed is the interrelation between agency theory, entity theory and 'the sacred and divide' thought of Robert Laughin. Indonesian accounting standard for Non-Profit organization (PSAK No. 45 ) is not taken into consideration in this church accounting because it has elements of secularism that are not in line with the ecclesiastical principle of sacredness. Recommendations of Booth and Laughlin which were then modified without eliminating essential assumptions and referring to the Bible as a normative source, are adjusted to the current church accounting practice. The theory of cognitive psychology proposed by Robert Sternberg was employed in the reconstruction. Church accounting that focuses on God, not only on material matters, can be reconstructed. Further, it is necessary to deconstruct the psychology of leaders and congregations.

This is an open access article under the CC-BY-SA license

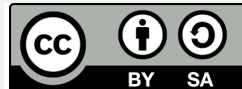

\section{Introduction}

The increasingly rapid growth in the public sector, especially that are based on social/religious foundations, creates a separate concern in terms of accountability [1]. Concerns about the lack of good accounting practices in non-profit organizations as a form of accountability to leaders have also been numerously expressed [2]. Discussing the relationship between religion and accounting is very interesting. The number of research that discusses this relationship is also increasing. Accounting concepts and practices can be linked to any religion, as well as philosophy [3]. In Indonesia, the church is one form of non-profit organization in the religious field, in accordance with PSAK No. 45/2011 concerning Financial Reporting of Non-Profit Organizations. A not-for-profit organization or a non-profit organization is an organization whose main objective is to support an issue or issue in attracting public attention for a non-commercial purpose, without any attention to matters of a profit-seeking monetary nature. The church is required to make financial reports, in the context of accountability and financial transparency for use in decision making in the organization. Accountability, namely the obligation to report and be responsible for the success or failure of the implementation of the organization's vision, is claimed to be necessary.

Church accounting practices started from Western churches such as in the Roman Catholic diocese [4] but very few have tried to conduct research that attempts to explain the accounting practices used [5]. Accounting practices at that time were determined from 
annual reports and evaluated based on the criteria and statements of the accounting profession in accordance with the reporting practices desired by the Roman Catholic church at that time [1]. Research on the financial accounting practices of the Church in Indonesia has been carried out [6] [7] [8] [9] [10] [11] [12][13][14][15], discussing the general application of Church accounting which employs PSAK No. 45. Whereas the church is required to prepare a financial report consisting of a financial position report that explains the assets and debts of the church, an activity report that explains the financial activities that occur in the church, namely cash receipts and expenditures, a cash flow statement that explains cash flows from operating activities, investment activity and funding activity.

Different issue [3] on the disclosure of spiritual accountability practices and reconstructing accounting concepts from local cultural values was tackled through interpretive approaches and ethnographic methods. The results of his research reveal the meaning of spiritual accountability with four meanings, namely: serving wholeheartedly, to sacrifice for the continuation of the organization, choosing a consecrated life and serving wholeheartedly. This research also reconstructs the concept of accountability within the framework of local cultural values using the original religious beliefs of the people of the Islamic faith called Aluk-ta by placing the church as a Tongkonan as the center of religious activity for its members.

Similar research conducted found that the daily activities of the IONA community based on Christian rules include cash receipts and use of offerings and operating costs recorded and each member has the right to ask for an explanation of the use of these funds [16]. This shows that the accountability report of the receipt and use of funds is a form of transparency and reflects spiritual and religious reflection. In contrast to Saerang (2001) which states that accountability in the pantecostal church regarding tithes, offerings, love and donations received from the congregation which is collective, has never been reported as being used as other non-profit organizations based on PSAK 45. In this way, accountability in church organization is limited to the daily behavior of church leaders. However, it has been debated that the Church is a place to justify actions based on God's Word [17]. In order to understand accounting, the research claimed that one does not need evidence and rational thinking. Likewise it has been argued that an understanding of variations in the accounting system must be linked to an understanding of the social dynamics of the church so that the use of sacred and secular metaphors separates the legitimate part of a church from its professed support activities [18]. Accounting is considered irrelevant to organizational life and is only tolerated insofar as it supports sacred things [19]. On the other hand, it has been said that there is a concern with the incompetence of accounting practices in the church so that the church tends to make accounting practices like commercial accounting practices [4]. The paper further put forward the reasons for the use of agency theory for financial reporting in churches and variations in their reports based on what they find in Roman Catholic dioceses. However, in a survey conducted using the telephone regarding capital and operational budgets in independent religious institutions which are also often referred to as purely non-profit organizations, it is stated that using the financial theory recommended by agency theory is too sophisticated to be carried out in non-profit financial institutions [20], because it is constrained by the readiness of human resources who still need financial training.

From several studies, it can be seen that the position of the church and accounting seems to be reversed. The church should dominate accounting, not accounting that dominates the church. It is the accounting that should adapt to the style of the church and not the church that has to adapt to accounting. Several months ago, social media highlighted the lifestyle of pastors, money and business in giant churches. In Indonesia, 
there are several synods or religious institutions that give freedom to each church to manage its own finances. This also applies to the giant churches that the author mentioned above. It is called a giant church because it has a very large number of congregations. Independent financial management by each church raises new problems, including the tithe of the congregation, which is managed privately by the pastor. Other churches may not provide financial reporting. This problem raised suspicions in the congregation so that there was no longer any element of belief in the pastor.

It is true that in the Bible it has been regulated regarding the tithe, namely in the Book of Malachi, namely, "Bring the entire tithe offering into the treasury, so that there is food supply in my house and test me, says the Lord of hosts, will I not open for you the windows of heaven and pour out bless you to the abundance." However, many church leaders have misinterpreted this verse, as proven with the increasing highlight on the pastor's riches.

Along with the times, the church is increasingly being carried away by the flow of secularism, which is more concerned with material welfare, even laden with politics of wealth interests. Such a phenomenon that occurs in one of the giant churches in Java by the highest leadership seat in the church, or what is commonly referred to as the pastor. The church is no longer a place to seek God but a place to seek wealth. This is because modern accounting has entered the church so that the behavior of people in the church has been carried over to western currents.

As previously explained, church accounting research in Indonesia is still dominated by the application of accounting based on PSAK No. 45 where this statement is designed for the preparation of financial reports for profit-oriented companies. However, even if in this standard what is regulated is the preparation of non-profit-oriented or non-profit financial statements, it can be seen from the elements of the reports that are presented that there are no significant differences. Elements of materiality and wealth as in agency theory are still prioritized. This theory is also a derivative of the prisoner dilemma theory, which makes it unsuitable to be used in a religious institution. How can a church accounting uses the theory of "thieves" in its reporting, when in the holy Bible it is clearly written that "it is forbidden to steal" and "it is forbidden to want something that is not ours ".

Therefore, the focus of this article is to reconstruct a new concept in church accounting that is in line with religion and spirituality. This responsibility is not only to humans as members of the church, but especially to God Almighty. Changing something that has been done for a long time is very difficult. It takes a change in the mindset of the congregation and then gradually from the church leaders to the synod leaders. This paradigm shift starts from the lowest level, namely the congregation, to the top leaders in the synod.

\section{Method}

This article uses the postmodern paradigm. This article rejects the use of PSAK No. 45 on non-profit organizations in Church accounting, because the rationale used in PSAK is Agency Theory. The assumptions used by Agency Theory which implies opportunistic trait of humans, are not in line with the essence of the church itself. To reconstruct church accounting that focuses on God not on material matters, it is necessary to deconstruct the psychology of leaders and congregations. The theory of cognitive psychology proposed by Robert Sternberg was then employed as reconstruction tool.

\section{Results and Discussion}

\subsection{God, Church and Accounting.}

Religion and accounting are two different social institutions, although they can be related to one another. One of the important scientists who studied this matter is 
max1weber in his book The Protestant Ethic and Spirit of Capitalism [21] which states that there is a mutually supportive relationship between the advancement of capitalism and the spirit of the Protestant. Capitalism has been described as a thought and habit that supports rational economic gain and shows a new economic condition, namely capitalist [21]. The spirit of rationalism brought by Max Weber can be seen from his statement, namely: a rational industrial organization cannot possibly be juxtaposed with an ordinary market because it does not have elements of political interests that act rationally and speculatively for profit, which is the only interest of western capitalism. The modern rational organization of the capitalist would not be possible without the existence of two important factors, namely the separation of business and household which dominates the modern economy (Entity theory) and the most related to it is rational bookkeeping (accounting).

In addition, the initiation of capitalistic attitudes in western civilization, namely: types of Protestantism that support work activities that seek profit, rational economics and worldly activities acquire positive spiritual and moral meanings [21]. Thus, the religious authority of Protestants shows that world success is a measure of salvation. Even Luther provided early support for the division of labor, which was beginning to develop in Europe. Therefore, according to Weber on the statement conveyed by Luther, God is no longer limited to religious people or churches but applies to any work or business. Support for the division of labor is the origin of the capitalistic labor organization, which is a problem today. The bourgeois capitalists are aware of this rational organization even though it may only be happening in the west. We also need to know where this rationalist thinking of capitalism comes from. This starts from the thought of natural science which fundamentally relies on the peculiarities of modern science based on mathematics and exact and rational experiments. Where the technical use of scientific knowledge is important in economic considerations that greatly benefit the West.

The origin of this thought is that Christianity has a positive impact on the world. The concept that developed among Protestants was the concept of calling [21]. This concept is a new religious concept during the reform era. Weber further explains that the important meaning of the concept of vocation in Protestantism is to make the ordinary affairs of everyday life under the influence of religion. A vocation for someone is an effort madel to carry out obligations towards God in a way of moral conduct in daily life. Vocation is also a way of life in accordance with God's will, by fulfilling the obligations that have been imposed on him in accordance with his position in the world. Yet for Weber, the vocation as understood by Luther is still a traditionalist. This is because of its strong emphasis on the element of one's fate, it remains in its place according to what God has ordained. So it is very unlikely for Luther to develop a fundamental relationship between worldly activities and religious principles.

This teaching was later passed on by Calvin. Calvin claims that the world exists to serve God [1] and only exists for that purpose alone. Christians in the world are only meant to glorify God by obeying His words according to their individual capacities. In addition, Calvin also argues that because there is a thought that everything is from God, God knows everything about human life. Hence, it can be concluded that from the beginning everything has been determined by God and no human can change the destiny that has been determined by God. This teaching is the starting point for the reform of the Church. Where previously property and wealth became a great force for human life so that it was far from religious elements. Capitalism has an important role because the foundation of the mechanism that is built comes from it. Capitalism indirectly removes divine lights from man because the calling of belief in God is dead. As it has been explained, calling can be indirectly related to religiosity. However, with the disappearance of this vocation, what dominates is the search for wealth and materiality of a worldly nature. It can also be 
explained that the church is in the prison of capitalism, thus the character of religiosity will also be eroded by capitalism. This raises a question: who can survive in that prison? Will new experts be born and bring the church out of this problem? Or in the end, will these experts be born but without the spirit of God, but a spirit of satisfaction of lust without a heart?

The paradox that Weber finds is that Protestantism encourages its congregation to follow worldly vocation in life that allows it to earn as much money as possible. However, according to Calvin, when the congregation uses property for personal gain it is considered a sin. To counter this paradox, Weber gave great support to the birth of capitalism. It is undeniable that if we look at job statistics from any country that has a mixed religious composition, the fact that business leaders and owners of capital and skilled labor have a higher and even higher level of corporate personnel, most of whom are religious. Protestant. It can be concluded that the origin of capitalism comes from Protestants.

There is also a problem in the church that the church entities are seen as not neutral and an indication of corruption. Because according to Luther's understanding, the church contains various kinds of evils, especially the issue of the letter of expiation of sins and the papal system. The power of the pope is too absolute, and this "absolutism" and has led to worldly elements, where the pope has the right to determine who goes to heaven and hell and determine how much tax should be imposed. Ironically, this is the cause of religious restraints on humans. Even Calvin considered that the church had lost the vision and mission of Christianity in which religion was present to save and prosper mankind and not to make people completely follow religious teachings. Next, came the church reformation which was symbolized by the power of church functions which was marked by removing deviant religious rules [1] and putting the church back into heaven's affairs. This major change had an impact on the performance of economic modernity so that the notions of liberalism, democracy and pragmatism emerged.

The development of the ideas of modern capitalism began with the pursuit of wealth. It is then that accounting overcomes and leaves the underlying religion. The spirit of Weber's capitalism is more towards the spirit of rationalism. Weber also criticized Karl Max and the resulting theories. That all human institutions, including religions, are based on the economy, so that the religious movement strengthens capitalism. Max Weber's writings provide enlightenment that accounting has long been included in the church environment and has influenced its aspects. Even accounting is accused of eliminating religious elements in a church, since every congregation is encouraged to seek wealth so that the behavior that is created is the behavior of a capitalist who is increasingly imprisoned for material wealth and forgets God. The behavior adopted is to remain obedient to religion, but at the same time still continues to run a business for profit and wealth based on the principle of calling which God has commanded to the chosen people.

Accounting has been far from a spiritual element because it has done worldly (secular) things from thoughts and mindsets by messing up the synergy of subjectivity and objectivity which only emphasizes the elements of welfare and materiality which are centered on political interests alone [22]. Modern accounting today is always symbolized by the process of company activities, which are used as a means of financial recording. Likewise, what happened in the church which interpreted accounting was only limited to financial information. This cannot be denied because if you look at the evolution of accounting itself, it begins with total devotion to God (Goddes accounting), centered on God (Hisbah Accounting) which then occurs a shift towards secular (Weberian double book keeping) where believing that God does exist but only to the extent that they are acknowledged as the creator of the universe, the rest becomes a human affair, and then the 
current accounting does not think that God exists. In this perspective, there are only elements of world interests and human happiness in the world.

It has been revealed about three thoughts on the current reality of accounting, namely personal interests, political power and relativity which can be concluded as secularity [22][23]. This also happens in churches where the pastor / church leader has a personal interest in the congregation, especially if the church is categorized as a giant church where the source of income is large congregational tithes and there is no adequate financial supervision. It is very ironic that religious leaders are also involved in political matters. These things are part of the secularism view that exists in religious institutions, which shows the theological level to be rationality so that it places rationality as its only strength.

\subsection{Loss of God in Church accounting}

Historically, accounting did not come from secular and capitalistic but came from Muslim traders who brought accounting to Italy which was later seen by Luca Pacioli. Luca Pacioli was established as the father of accounting because of his book summa de arithmetica, by the misguided orientalists [24]. We can see the spiritual traces of accounting in a double book keeping which writes "in the name of God". Hence, we can conclude that even though accounting is only a tool, accounting comes from spiritual and belief elements so that it is very possible to be applied in religious organizations such as the Church.

Church accounting has developed in line with the modernity of society with a global view. We can see from the church accounting studies in Indonesia where the institution prepares financial reports based on PSAK no.45 on Non-Profit Organizations where the elements contained in the financial statements use conventional accounting sequences such as accruals and going concern concepts. This development is in line with the evolution of Auguste Comte in his book "Cours Philie (1842) and systeme de politique positive" (1851), where Comte believes that the religion of humanity which is achieved at the peak of positivism is a success factor for self-happiness in building social order. From the viewpoint of Comte, positivism it can be seen that positivism reduces the Protestant and Jewish values that are inherent in accounting. Accounting has become a soulless / religious neoliberalism with a belief in a rational market which then forms a new social order reality. In order to create a new better social order, the evolution of human knowledge and the social order proceeds through three stages of development of the rationalization of reality. The three levels are theological, metaphysical and positive.

Accounting has changed its own way of thinking and science by not synergizing subjectivity, partiality, religion into something common which of course only thinks of an objective reality on behalf of welfare which is the political interests of wealth which is described in accounting that wealth is an asset, this is what includes evolusionists' thinking from proprietary theory to entity theory [22]. The purpose of this theory is to provide information and make a wealth analysis of the economic activities of the company (owner). Chow (1942) said that proprietorship indirectly provided an increase in income and minimized costs in corporate financial activities. It can be analogized, when companies develop and evolve into large corporations and free market issues, that's when the concept of entity theory pays attention to economic units.

The economic unit in question is not meant to be something that is served but on the contrary, the unit must serve the owner (Suwardjono, 2005). The orientation of the entity theory is on income, so it can be said that the level of owner's trust in the economic unit is carried out by measuring activity and financial achievements collectively.

It was stated that accounting in the Roman Catholic church has used agency theory as the center of its thinking [4]. Kusdewanti (2013) explains that Agency Theory is a foundation of the sociological theory of human relations and is also the basis of accounting 
research which is then quoted by positive accounting theory [25]. The basic values of agency theory begin with the neoclassical economy which is included in accounting [26]. The nature of agency theory is that humans are rational economic humans who have selfrighteousness and always lead to logic-based actions for material satisfaction and wealth [27]. Agency theory suggests that there is a relationship between principal and agent, where the relationship is contractually established because of an interest orientation, namely income oriented. The interest orientation arises because it is a reflection of the entity theory which is also income-oriented [28].

When the church applies accounting with an understanding such as agency theory, it creates a separation of relationships between humans. A research found that agent behavior depends on the contract being carried out [29]. The only thing that connects is a contract in which contains incentives as a substitute for the principal's expectations of agent behavior. The phenomenon that occurs is exactly the same as what Jensen said, especially in giant churches, that when a servant of God is in charge of worship, there will be an incentive received. Service is no longer based on a personal desire to serve God but because there is a contractual relationship that occurs between church leaders and God's servants. The negation shows that humans are confined in their own world designed only by contract. In the context of the separation from the relationship with itself, this is a form of weakness from the assumption that agency theory is unable to see itself. This is evidenced from the viewpoint of human self-interest, and every behavior is driven only by money motivation alone. This assumption implies that humans are creatures that have a material orientation, even though humans consist of body, soul and spirit [30].

After being separated from himself, human is next is separated from his/her relationship with God. The only assumption held by agency theory is the value of capitalism. In the end, lost relationship with God will only harm oneself and others. The spirit of rationalism that is carried means breaking away from the spiritual so that it becomes different to the spirit that exists in the church, namely bringing all congregations back to have an intimate relationship with God [21].

In the end a big question arises: where is God in accounting? If accounting only takes shape through social, cultural, political and ideological dimensions then there is no place for God. In this way, accounting is just an economic reality. Likewise with agency theory which may only be seen from the goals, the ideology it carries create the present realities.

Agency theory talks about the contractual relationship between principal and agent. In this relationship, there is a very close relationship with game theory. Game theoretical models are a reference for solving behavioral problems in agency theory. It has been implied that the agent problem occurs in small and large games such as markets. We can define that the game is a relationship between several agents with rules that will determine the likelihood of activity that the agent will carry out along with its consequences [23]. This means that there will be rules made to produce a social relationship between the principal and agent. The agency relationship or the relationship between the principal and the agent is part of the economic dimension that includes all dimensions [31]. This is in line with Von Neuman's thought that game theory can enter all dimensions through mathematical thinking.

From a contractual relationship actually indirectly is the impact of distrust, because there will always be those who monitor the actions of the agent for the benefit of the principal. Agency theory also raises discretion and strength in information in the form of systems [32]. We can conclude that agency theory is a form of application of game theory. Accounting is a part of social science that becomes complicated because values and morals are included so that accounting can be said to be not objective in value. Accounting practice is trapped in the calculation of profit alone and leaves the divine element. The self- 
interest brought about by agency theory can bring disaster [33]. The same thing was also expressed by Madjid (2005) that every person created by God is obliged to look after each other without humiliating others.

It cannot be denied that western culture has greatly influenced the development of church accounting today. The culture from the west that was colonial in nature gave birth to an accounting concept that was like this. The culture is even more developed today than eastern culture. Therefore it takes a whole principle to see this point of view. The only way is to return to the Bible as the source of Christian life, where every believer must understand the concept of the real kingdom of God. Where this concept puts forward the first: focus on God, there is no interest in the congregation but only the interests of God, second: there is no self-interest in the kingdom of God, because the enemy of God's kingdom is only the kingdom of the ego. The third is mutual love. It is written in the Bible that you must love one another as God has loved you.

\subsection{Deconstruction using psychological theory}

To change something that has been in use for a long time will be very difficult, especially the thought of rationalism which has long been included in Protestantism. A treatment to change the mindset for both church leaders, congregations and from the aspect of their organizational structure is needed. The theory of cognitive psychology put forward states that cognitive psychology is how people perceive, learn and think about information [34]. Why does it need a cognitive psychological theory in undermining agency theory that has long been included in Protestants? If we know where we came from, we might have a better understanding of where we're going. In addition, we can learn from past mistakes.

According to Oslo (2008) cognitive psychology is the science of information processing starting from how to obtain and process information about the world, how this information is stored and processed by the brain, how we solve problems, think and compose language and how these processes are displayed in behavior, which can be observed.

In cognitive psychological theory, it is also known as short-term and long-term memory theories. Related to the phenomena raised in this article shows that there is a longterm memory from Protestants regarding rationalism that must be constructed from rational to Christ-centered. If we look at the history of the development of accounting, which began that there is God in accounting and then accounting has become secular until now there is no God in accounting, according to Robert Oslo (2008) that the occurrence of memory reconstruction in accounting, first is the removal of information. Some specific information is lost, besides information that is not logical or does not match expectations tends to be difficult for the participants to remember. Then in the next stage is rationalization, where a number of information is added in such a way in an effort to clarify the parts of memory that are incongruent or illogical so that a dominant theme or a strongly remembered theme emerges.

When accounting entered the church and influenced the aspects therein, at that time secularism also entered the church and until now it controls the church, especially the Protestants with a spirit of rationalism. This has become a habit (Habit), if in psychology the spirit of rationalism has become a long-term memory because it is repeated every day so it is very difficult to change this habit. Therefore, meditation is needed (Robert Oslo, 2008) to increase awareness of God. To restore one's awareness to focus on God, it is necessary to disintegrate oneself first. That the congregation must understand that this life is only God's grace alone. So that the congregation and church leaders must first heal the past or forgive things that happened in the past. Likewise, church accounting is currently being used, namely secular accounting. The church needs to realize in advance that something is irrelevant if the church applies these rules. In order to make the church 
leaders aware of this, it is necessary to reconstruct the thoughts of the church leaders and the congregation.

When the church leaders realize this, every root of secularism is removed from their minds and then filled with the words of God that strengthen their faith in God. This is meant that when the old paradigm breaks down, it must be filled with new paradigms continuously until finally changes can be seen. To change a large religious organization is very difficult because many people are involved in it. This can be started with local churches which have the authority to manage their own finances.

\subsection{Accounting for the Kingdom of God}

Church-related accounting research literature is generally based on local history. Several studies have addressed the accounting practices of commune-type religions during the early history of the United States [5]. It has been described that the management accounting techniques that developed and used by society and became a harmony in the early 1800s [35]. However, the research conducted by (Booth, 1993) also presents problems in the organization, namely that although both are religiously based, on the other hand they are also actively involved in business activities. At that time church members were more concerned about their economic independence.

Studies conducted provide several indications that accounting practices can interact with the spiritual dimension of the church [5]. The use of accounting is thought to be related to the management problems involved with the survival of the church and to being involved in the centralization of control. The survival of the church indicated in his research is also in line with what is in the theory of entities that also focus on corporate survival [1]. Furthermore, his analysis was begun by looking at the historical financial patterns in the Church of England, and some of the major events in the history of the development of major organizational units and their financial relationships [36]. The analysis of accounting practice focuses on the systems used in three specific locations: the parish, its diocese, and the church's main organizational unit.

Laughlin argues that this understanding of diversity in the accounting systems of the English church website must be linked to an understanding of the social dynamics of the church, certain local factors and dominant actors. A metaphor of separation between sacred/ holy and secular/ worldly where the role system plays is the belief of religious organizations in accounting was used [18], but the phenomenon that occurs is that the level of trust referred to by Laughlin then becomes shifted more towards accountability for the use of finances that are not based on trust among the congregation. The condition of the church today is difficult to distinguish between sacred and secular areas, so this should be the main concern of the church, because it is to separate the sacred part of the church and other supporting activities.

In the church, accounting is seen as a supporting activity and as such is not considered sacred. At least there are several things that cause this: first, the increased democratization in the church that involves many lay people in the performance of tasks, resulting in this sacred domination has led to the development of a spiritual control system to secular needs. For example, when giving (offerings) it should be related to the spiritual awareness of its members, not the necessary expenses and obligations of the church. Also the practice of budgeting in the church is less relevant as a planning tool as well as decision making that tends to be influenced by financial implications.

The circumstances in which increased activity costs and reduced sources of income put the church under increased financial pressure. This expands the use of the accounting system as a way of responding to the context of church resources as well, therefore it is an important factor in understanding the significance of accounting variables. Various organizational factors, such as the need to allow structurally for a secular support system 
and the degree of financial stress, are seen as potential mediating factors in the accounting breakdown into church life. In other words, Laughlin's study allows very detailed insight into the how, who, when and why of accounting practices in the church.

This study emphasizes the importance of understanding the role of the church belief system as a major source of resistance to the use of accounting. Finally, the need for the church to have a secular support function and the importance of this function being variable with the degree of financial pressure experienced by the organization as a whole or within individual units, is identified as potentially important mitigating conditions for taking action on the social dynamics surrounding the accounting system.

\subsubsection{The belief system in the Church}

The belief system in the church is a key factor in understanding accounting in the church [18]. The importance of religious belief systems in understanding the management and structuring of religious organizations has been a theme in the organizational studies related literature [37]. In this comprehensive review of much of the literature, Thompson (1975) argues that belief systems are the primary criterion of legitimacy in religious organizations. His own study of the Church of Great Britain (Thompson, 1970) illustrates how the preservation of basic organizational identities was a major factor in how the church responded to organizational change throughout its history.

However, it has also been emphasized that in any part of history, church identity has greatly influenced the process of change where there will be a period of power struggles between different groups in the church [18]. The intended identity is not a name in the organization but the values contained in the organization. The importance of retelling the history of the founding of the church is important to minimize conflicts of interest that exist in the church. The identity of the church must be based on historical values. The phenomena occurring in churches in North Sulawesi have led to an identity crisis, where the church no longer differentiates between sacred and secular. Therefore the importance of understanding the kingdom of God in the church is the first step to create a new concept in church financial statements. If the church still uses reporting based on PSAK, it can still be said that the church uses secular matters in arranging sacred things.

\subsubsection{Workers' members and groups}

The members referred to are key members in analyzing the church [5]. Therefore, every member must have a voluntary nature in doing church work and are required to follow the spiritual journey of the church to instill the values and history of the church. In summary, the interpretations and actions of church and group occupational members have argued to be potentially important explanatory factors in the process of resistance to accounting in these organizations. The current phenomenon is that church members and pastors do not support the use of accounting in the church. As previously explained, there are several church synods that allow branch churches to manage their own finances. The only source of income for the church comes from the congregational tithes and congregational offerings. In many churches this is what often does not support accounting in the church.

The dynamic nature of members, pastors, accountants and other groups of workers may lead to different interpretations so that a systematic explanation is needed. It cannot be denied that accounting practices in the church will experience pros and cons in reporting, therefore it requires a common perception regarding the financial management of the church.

\subsection{Organizational Resources}

The most significant of organizational resources are the various concepts about the resource level, which are the starting point by which to consider such a possibility; membership size and financial resources. The availability of financial resources has been 
shown to influence how management problems are viewed and addressed in the church. Laughlin argues that financial pressure is a condition that allows and becomes significant in reducing the level of resistance to the use of accounting for certain purposes as in the case of the church in England. Similar to a strong membership position, abundant financial resources can reinforce the dominant position of religious belief, with issues of secular financial management more likely to be seen as less important for continued operations in such conditions. Both in the church and in the secular, if the lack of financial resources will cause new problems. This is what challenges the church today so as not to be trapped in secular management methods and to maintain the sanctity of the church.

Lack of financial resources can be caused by declining church members. However, we cannot categorize the number of members and financial receipts (Harris, 1969). Therefore, it is important for the church, especially the pastor, to give the congregation members an understanding that giving offerings is not just a formality but giving offerings is a form of gratitude for the congregation for God's loyal love, which has been previously expressed. The size of an offering is not measured by how many rupiahs it is given but from a sincere heart to give. The Bible tells a story of a poor widow who gave an offering of only five cents, so that the crowd insulted her. But what did God say? Blessed is the gift of the poor widow because she gave not from the excess she had but she gave all that was to her with a willing heart. The importance of having an attitude of willingness to give to the congregation is imperative. Rich and poor also do not matter how much your house, car and position, but rich and poor only talk about a person's mental state.

Strong membership and / or financial resource positions can be expected to strengthen religious dominance, and thus also maintain or increase the level of accounting resistance. Here is a simple metaphor which is modified from the metaphor of "The sacred and secular divide by [36].

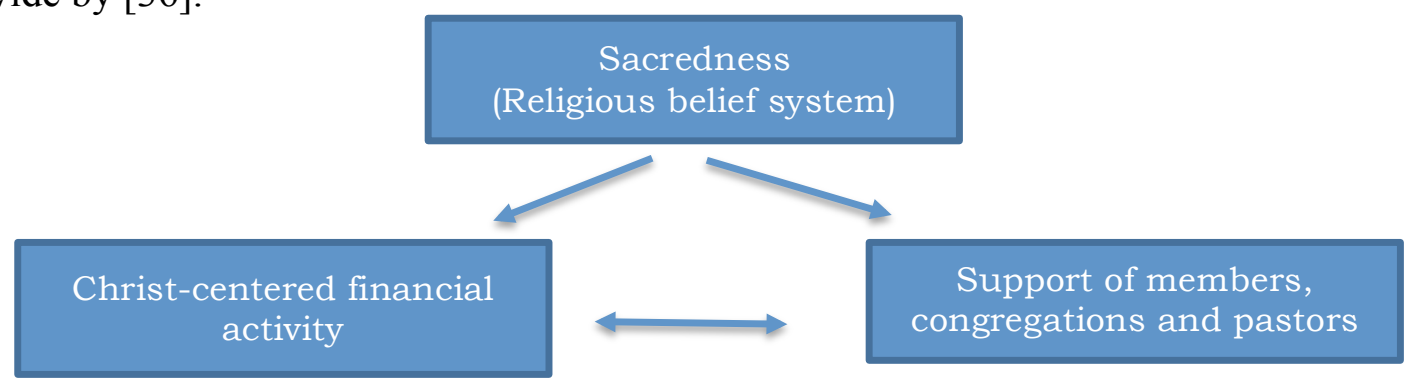

Figure 1. Modification of The Sacred and Secular Divide Metaphor

The understanding of the Kingdom of God in the church's financial system can be seen from the metaphor above that sanctification is the most important thing in every activity in the church, both financial and non-financial. Therefore it should not be confused with secularism. Although there are several elements that are obtained from secularism such as education, sanctity is the dominant thing. It is important to understand that the center of human life is Christ to be a fortress in every activity that we will do so that as it is written in the Bible that "Whatever you do, do with all your heart as for God and not for humans". Financial issues are very sensitive not only secularly but in the church too so that the focus on Christ becomes the main thing. When a member or accountant is doing his job and understands that what he is doing is for God, no cheating will be done and he will automatically be trustworthy for every job done.

Christ-centered financial activities must be supported by both church members and pastors because in them there are elements of indirect trust. Unlike the case with agency theory, the element of belief is a contractual relationship, so the church does not do this. In addition, it is important for church members to know that in the management of church 
finances there is no separation of ownership between the pastor (Principal) and the congregation (Agent), not as described in entity theory. It is unethical if the church applies entity theory in which the offerings of the congregation must be separated. It is clear in the Bible that it is written: "take each of your gifts to the house of God so that there will be a supply of food and drink". Therefore, it is irrelevant if the church uses entity theory. PSAK No. 45 should not be used in the church, since it has elements of agency theory and entity theory which is a derivative of the Prisoners' Dilemma Theory. Does the church use the Prisoners' Dilemma or "Thief" theory? In the Bible, one of the ten laws of God is clearly stated "do not steal"

The concept of accounting with the understanding of kingdom of God is needed so that the church returns to the center of sacredness, namely the Lord Jesus so that the behavior of the congregation will slowly change from capitalist to religious which does not prioritize wealth and materiality.

\section{Conclusion}

The development of science also had an impact on the church. Today, church has been carried away by secularism and has forgotten its sacredness with God. The congregation tends to also forget accountability to God, and prioritizes worldly interests, namely seeking wealth and materiality. The church is no longer a place to seek God but a place to exchange information on secularism. This also affects Church accounting, where the current application of church accounting is based on PSAK No.45, which incidentally is a product of secularism.

Accounting today has separated from God. The history of the development of accounting was initiated as godly accounting. However, as the notion of capitalism pervades which was more concerned with pursuing wealth than God, then came the notion of Calvinism where they stated that God does exist but only as a creator, other matters in the world are the responsibility of humans. With these understandings, accounting has become secular and even today accounting is godless.

Understanding the Kingdom of God will restore the true essence of accounting, especially in the Church, where, Christ is the main focus. When we put Christ above all things good things will follow. The accounting concept offered is a modification of the framework of Laughlin who conducted research in churches in England and found that there were problems regarding what accounting was in the church and how accounting was applied in the church at that time.

\section{References}

[1] Booth P. Accounting in Churches: A Research Framework and Agenda. Accounting, Audit Account J 1993. doi:10.1108/09513579310045684.

[2] Lamsal M. The Structuration Approach of Anthony Giddens. Himal J Sociol Anthropol 2012. doi:10.3126/hjsa.v5i0.7043.

[3] Randa F, Triyuwono I, Ludigdo U, Sukoharsono EG. Studi Etnografi Akuntabilitas Spiritual pada Organisasi Gereja Katolik yang Terinkulturasi Budaya Lokal. J Akunt Multiparadigma 2011. doi:10.18202/jamal.2011.04.7109.

[4] Rowe TM, Giroux GA. Diocesan financial disclosure: A quality assessment. J Account Public Policy 1986. doi:10.1016/0278-4254(86)90006-2.

[5] Booth P. Accounting in Churches: A Research framework and Agenda. Eletronic Libr 2015;34:1-5.

[6] Kaomaneng IS. Penerapan Sistem Akuntasi Dalam Pengelolaan Keuangan Gereja. J Uniera 2011.

[7] Pontoh CRS. Penerapan Laporan Keuangan Organisasi Nirlaba Berdasarkan Psak 
No 45 Pada Gereja Bzl. J Ris Ekon Manajemen, Bisnis Dan Akunt 2013.

[8] Dewi, K.G.S.S., Atmadja, A.W.T., dan Adiputra M. Konsep Akuntabilitas Keuangan Dalam Organisasi Keagamaan (Studi Kasus Pada Gereja Kerasulan Baru Di Indonesia, Distrik Jawa Timur Dan Bali). JIMAT (Jurnal Ilm Mhs Akunt S1) 2015.

[9] Kabuhung M. Sistem Informasi Akuntansi Penerimaan Dan Pengeluaran Kas Untuk Perencanaan Dan Pengendalian Keuangan Pada Organisasi Nirlaba Keagamaan. J Ekon Dan Bisnis 2013. doi:10.1017/CBO9781107415324.004.

[10] Naten S. Evaluasi Sistem Pengendalian Intern Penerimaan dan Pengeluaran Kas untuk Organisasi Non Profit ( Studi Empiris pada Jemaat GPM Amahusu ). J Biosainstek 2020.

[11] Mamesah M. Penerapan PSAK No.45 Pada Gmim Efrata Sentrum Sonder Kaitannya Dengan Kualitas Informasi Laporan Keuangan. J Ris Ekon Manajemen, Bisnis Dan Akunt 2013. doi:10.35794/emba.v1i4.3368.

[12] Bigky FM, Rahmah M. Perlakuan Akuntansi Organisasi Nirlaba Terkait Dengan PSAK No.45 Tahun 2017 Pada Gereja HKBP Maranatha. J Akunt Dan Bisnis Krisnadwipayana 2019.

[13] Wijaya LC, Prasetyo W, Kustono AS. Konsep Akuntabilitas dalam Gereja Katolik. J Ekon Akunt Dan Manaj 2020. doi:10.19184/jeam.v19i2.15115.

[14] Gultom IR, Poputra A. Analisis Penerapan PSAK No.45 Tentang Laporan Keuangan Organisasi Nirlaba dalam Mencapai Transparansi dan Akuntabilitas Kantor Sinode Gmim. J Ris Ekon Manajemen, Bisnis Dan Akunt 2015.

[15] Kumambow L, Tinangon JJ, Tirayoh VZ. Penerapan Psak No. 45 Pada Gereja Gmim Bukit Zaitun Walian Dua. Going Concern J Ris Akunt 2015. doi:10.32400/gc.10.2.8371.2015.

[16] Jacobs K, Walker SP. Accounting and accountability in the Iona Community. Accounting, Audit Account J 2004. doi:10.1108/09513570410545786.

[17] Burrell M. Burrell and Morgan ‘s. Sociol J Br Sociol Assoc 1979.

[18] Laughlin RC. A Model Of Financial Accountability And The Church Of England. Financ Account Manag 1990. doi:10.1111/j.1468-0408.1990.tb00427.x.

[19] Abdul-Rahman AR, Goddard A. An Interpretive Inquiry of Accounting Practices in Religious Organisations. Financ Account Manag 1998. doi:10.1111/14680408.00060 .

[20] Zietlow JT. Capital And Operating Budgeting Practices In Pure Nonprofit Organizations. Financ Account Manag 1989. doi:10.1111/j.14680408.1989.tb00320.x.

[21] Weber M. The protestant ethic and the spirit of capitalism. 2005. doi:10.4324/9780203995808.

[22] Mulawarman AD. Nyanyian Metodologi Akuntansi ala Nataatmadja: Melampaui Derridian Mengembangkan Pemikiran Bangsa "Sendiri." J Akunt Multiparadigma 2013;4. doi:10.18202/jamal.2013.04.7189.

[23] Watts RL. Accounting choice theory and market-based research in accounting. $\mathrm{Br}$ Account Rev 1992. doi:10.1016/S0890-8389(05)80023-X.

[24] Mulawarman AD, Kamayanti A. Towards Islamic Accounting Anthropology: How secular anthropology reshaped accounting in Indonesia. J Islam Account Bus Res 2018;9:629-47. doi:10.1108/JIABR-02-2015-0004.

[25] Gaffikin M. Accounting Theory and Practice: the Ethical Dimension. Univ Wollongong Res Online 2007.

[26] Chua WF. Accounting, measuring, reporting and strategizing - Re-using verbs: A review essay. Accounting, Organ Soc 2007. doi:10.1016/j.aos.2006.03.010. 
[27] Kusdewanti AI, Hatimah H. Membangun Akuntabilitas Profetik. J Akunt Multiparadigma 2016. doi:10.18202/jamal.2016.08.7018.

[28] Triyuwono I. Akuntansi Malangan: Salam Satu Jiwa dan Konsep Kinerja Klub Sepak Bola. J Akunt Multiparadigma 2015;6:290-303. doi:10.18202/jamal.2015.08.6023.

[29] Jensen M, Meckling W. Theory of the firm: Managerial behavior, agency costs, and ownership structure. Econ. Nat. Firm A Reader, Third Ed., 2012. doi:10.1017/CBO9780511817410.023.

[30] Sidiq A. Kidung Rumeksa Ing Wengi (Studi Tentang Naskah Klasik Bemuansa Islam). Analisa 2016. doi:10.18784/analisa.v15i01.328.

[31] Arrow K. Methodological individualism and social knowledge. Am Econ Rev 1994. doi:10.2307/2117792.

[32] Yamaji H. Accounting discourse as a process of implanting a social consciousness into the public mind. A re-reading of American accounting theories as mythology. Crit Perspect Account 2005. doi:10.1016/S1045-2354(03)00036-4.

[33] Kamla R. Critical insights into contemporary Islamic accounting. Crit Perspect Account 2009;20:921-32. doi:10.1016/j.cpa.2009.01.002.

[34] Stenberg R. Cognitive psychology. Neuropsychologia 1972;10:259. doi:10.1016/0028-3932(72)90070-x.

[35] Flesher TK, Flesher DL. Managerial accounting in an early 19th century GermanAmerican religious commune. Accounting, Organ Soc 1979. doi:10.1016/03613682(79)90020-5.

[36] Laughlin RC. Accounting in its Social Context: An Analysis of the Accounting Systems of the Church of England. Accounting, Audit Account J 1988. doi:10.1108/EUM0000000004622.

[37] Miley F, Read A. Suffer little children: Power, boundaries and the epistemology of ignorance in accounting for Church and State. Crit Perspect Account 2020:102162. doi:10.1016/j.cpa.2020.102162. 